Original Research Paper

\title{
Effect of Nano-Alumina on Pore Structure and Durability of Class F Fly Ash Self-Compacting Mortar
}

\author{
${ }^{1}$ Ehsan Mohseni and ${ }^{2}$ Konstantinos Daniel Tsavdaridis \\ ${ }^{I}$ Department of Civil Engineering, University of Guilan, Rasht, Iran \\ ${ }^{2}$ School of Civil Engineering, University of Leeds, Leeds, UK
}

\author{
Article history \\ Received: 17-03-2016 \\ Revised: $12-04-2016$ \\ Accepted: 13-04-2016 \\ Corresponding Author: \\ Ehsan Mohseni \\ Department of Civil \\ Engineering, University of \\ Guilan, Rasht, Iran \\ Email: E.mohseni1988@gmail.com
}

\begin{abstract}
In this study the effect of pore structure on the mechanical properties and durability characteristics of Self-Compacting Mortars (SCM) containing nano- $\mathrm{Al}_{2} \mathrm{O}_{3}$ (NA) and class $\mathrm{F}$ fly ash are investigated. $\mathrm{Al}_{2} \mathrm{O}_{3}$ nanoparticles with the maximum size of $15 \mathrm{~nm}$ in three different proportions of 1,3 and $5 \%$ of the binder content were utilized to partially replace the cement. The $25 \%$ of the cement weight was also replaced by class F fly ash. The pore structure of cement mortars was determined through the Mercury Intrusion Porosimetry (MIP) and Gas Adsorption (BET) methods. The microstructure of the SCMs was evaluated by Scanning Electron Microscopy (SEM). The results indicated a reasonable correlation which was observed between the pore structure and other properties of mortars. The addition of the NA at proportions over $1 \%$ led to an increase in the pore volume of specimens by virtue of agglomeration. In overall, it seems that $1 \%$ NA can be considered as a suitable replacement regarding the pore structure and hardened properties.
\end{abstract}

Keywords: $\mathrm{Nano}_{-} \mathrm{Al}_{2} \mathrm{O}_{3}$, Pore Structure, MIP, BET, Durability

\section{Introduction}

Over the last few decades, Self-Compacting Concrete (SCC) has gained great attention due to many advantages over conventional concrete. SCC is able to be compacted under its own weight without the need for vibration, segregation or bleeding. This results the SCC application to facilitate and ensure precise filling of restricted areas and heavily reinforced structural members (Nazari and Riahi, 2011a; Safiuddin et al., 2010; Oltulu and Sahin, 2013; Jalal et al., 2012; Madandoust et al., 2011).

The application of self-compacting mortar is one of the most active research areas in the field of both civil engineering and construction materials due to the benefits it offers in comparison with the SCC. For instance, measuring the rheological properties of SCC is often impractical in virtue of needing for sophisticated instruments. So laboratory tests of mortar are easier than those of concrete (Rashad, 2013).

Nowadays, nano-technology and nano-science can be defined as the exploration, innovation and application of nano-materials, which are characterized by at least one dimension in the nano-meter $(\mathrm{nm})$ range. The size range that attracts significant attention is below $100 \mathrm{~nm}$
(Chang, 2007). Researchers have already perfoemed studies on the application of materials in nano scale and/or pozzolanic materials in self-compacting mortar or concrete with scope to improve mechanical and physical properties (Barbhuiya, 2011; Hou et al., 2012; Madandoust et al., 2015; Mohseni et al., 2015a; 2015b; Yang et al., 2015). However, there is limited research concentrated on the cement-based materials properties containing nano- $\mathrm{Al}_{2} \mathrm{O}_{3}$ (Nazari and Riahi, $2011 \mathrm{~b}$; Li et al., 2006; Oltulu and Sahin, 2013; Barbhuiya et al., 2014). Jalal et al. (2012) investigated the effects of micro- and nano- $\mathrm{SiO}_{2}$ particles on the durability and micro structural of high-performance self-compacting concrete. The results indicated that using silica in nano and micro scale has a substantial impact on improving the properties of SCC. The addition of micro- and nano-particles of $\mathrm{SiO}_{2}$ has importantly reduced the $\mathrm{Cl}$ ion percentage and increased the electrical resistivity at later ages, namely for the mixtures with higher percentages of admixture. The impact of nano- $\mathrm{SiO}_{2}$, nano- $\mathrm{Al}_{2} \mathrm{O}_{3}$ and nano- $\mathrm{Fe}_{2} \mathrm{O}_{3}$ powders on the compressive strength and capillary water absorption of cement mortar containing fly ash was studied by Oltulu and Sahin (2013). It was found that nano-powders boost the pozzolanic activity and mechanical and physical 
properties of mortars can be improved. Madandoust et al. (2015) measured the durability of SCM mixtures containing $\mathrm{SiO}_{2}, \mathrm{Fe}_{2} \mathrm{O}_{3}$ and $\mathrm{CuO}$ nanoparticles in terms of electrical resistivity, permeable porosity, as well as capillary and water absorption. They reported the significant effect of nanoparticles on the durability properties of mortars. Dolomite powder was used as an alternative material instead of limestone powder in SCC by Barbhuiya (2011). The outcome was possibility of manufacturing SCC utilizing the FA and dolomite powder. In a study conducted by Nazari and Riahi (2011c), the effects of curing media on water permeability of concrete containing $\mathrm{TiO}_{2}$ nanoparticles were investigated. According to the results, the inclusion of nano- $\mathrm{TiO}_{2}$ improved the water permeability of the mixtures cured in saturated water in comparison with the samples cured in water. He and Shi (2008) reported that the inclusion of nanoparticles $\left(\mathrm{Fe}_{2} \mathrm{O}_{3}, \mathrm{Al}_{2} \mathrm{O}_{3}, \quad \mathrm{TiO}_{2}\right.$ and $\left.\mathrm{SiO}_{2}\right)$ and nano-clays (montmorillonite) promoted the chloride penetration resistance of the mortar, as indicated by the reduced apparent diffusion coefficients of chloride anion. Morsy et al. (2010) studied the compressive and tensile strength of mortars containing nano-clay. The cement was partially replaced with nano-clay at levels of 2, 4, 6 and $8 \%$, by weight. The results indicated an increase in both compressive and tensile strength with increasing nano-clay content. Kawashima et al. (2013) studied the compressive strength of pastes containing 30\% Fly Ash (FA) modified with 5 wt.\% nano- $\mathrm{CaCO}_{3}$ (NC). Pastes with NC were prepared with a suspension that was sonicated or blended. The results showed an increase in the compressive strength with the addition of nano$\mathrm{CaCO}_{3}$. Qian et al. (2009) studied the penetration of chloride ion of concretes containing FA modified with NC. The amount of $\mathrm{NC}$ was $2 \%$, by weight of the total binder. The results showed a reduction in the penetration of chloride ion with the addition of $\mathrm{NC}$.

In particular, the pore structure effects of nano- $\mathrm{Al}_{2} \mathrm{O}_{3}$, as a high surface area powder additive on the mechanical as well as the durability and microstructure properties of mortar, need to be fully recognized. Therefore, the present study is an endeavor to characterize the microstructure properties of SCM containing nanoparticles. Fresh mortar tests such as the slump-flow and V-funnel are employed to assess the workability of the matrix. Moreover, hardened mortar tests such as compressive strength, water absorption, electrical resistivity and Rapid Chloride Permeability Test (RCPT) were conducted to simulate the real-world applications and determine the optimal percentage of using such nanoparticles in SCM. Furthermore, the effects of nano$\mathrm{Al}_{2} \mathrm{O}_{3}$ (NA) on the pore structure were investigated by MIP and SEM micrographs.

\section{Materials and Methods}

\section{Materials and Mixtures}

In the present study, type II Portland cement (ASTM, 2001a) and class F fly ash were used. $25 \%$ of the weight of the cement was replaced with fly ash. A constant water-to-binder $(\mathrm{w} / \mathrm{b})$ ratio of 0.4 was also adopted. The physical properties and chemical composition of the cement and fly ash can be seen in Table 1. Natural river sand was used as fine aggregate. A dosage of super plasticizer with a density of $1.03 \mathrm{~g} / \mathrm{cm}^{3}$, according to (ASTM, 2001b) and TYPE F was utilized to accelerate the compacting process. The content of nanoparticles (1, 3 and 5\%) that partially replaced with cement was obtained followed by preliminary experimental tests. Nano- $\mathrm{Al}_{2} \mathrm{O}_{3}$ (NA) with a nearly spherical morphology and average particle size of $15 \mathrm{~nm}$, in a form of a dispersed suspension with $30 \mathrm{wt} \%$ in water, was used. The blain value and impurity of NA were $200 \mathrm{~m}^{2} / \mathrm{g}$ and $99.8 \%$, respectively. Figure $1 \mathrm{a}$ and $1 \mathrm{~b}$ demonstrates the X-Ray Diffraction (XRD) diagrams of FA and NA.

\section{Mixture Proportioning}

SCMs were mixed by means of a mechanical and rotational mixer according to ASTM C305. The process of preparing the specimens after conducting preliminary experiments was obtained as follows:

Sand and cement were mixed for approximately 1 min at the low speed of $80 \mathrm{rpm}$. Fly ash, $30 \%$ of water and nanoparticles were added and mixed speedily for about 1 min. Then the mixture was rested around 1.5 min. Finally, the rest of the water $(70 \%)$ was combined with the superplasticizer completely for $2 \mathrm{~min}$.

After the completion of initial fresh mortar tests, fresh mortar was cast into $50 \times 50 \times 50 \mathrm{~mm}$ cubes for the preparation of the compressive strength, water absorption and electrical resistivity tests, as well as $50 \times 50 \times 200 \mathrm{~mm}$ prism molds were cast for the flexural strength experiment. Also, $100 \times 50 \mathrm{~mm}$ cylinder molds were used for the RCPT. Each test result evaluation is the average of three test specimens. One day after the casting process, the samples were demolded and kept in water at a constant temperature of $20 \pm 1{ }^{\circ} \mathrm{C}$ until the testing day. Table 2 shows the mixture proportioning of specimens.

\section{Test Procedure}

Compressive strength test was performed in accordance with ASTM-C109 (ASTM, 2007a) using a hydraulic testing machine under load control at 1350 $\mathrm{N} / \mathrm{s}$. Flexural tests were carried out according to with the ASTM C293 (ASTM, 2007b) standard. The threepoint (i.e., Center-point) flexural tests were also carried out with a span of $180 \mathrm{~mm}$ and at a loading rate of $44 \mathrm{~N} / \mathrm{s}$. 

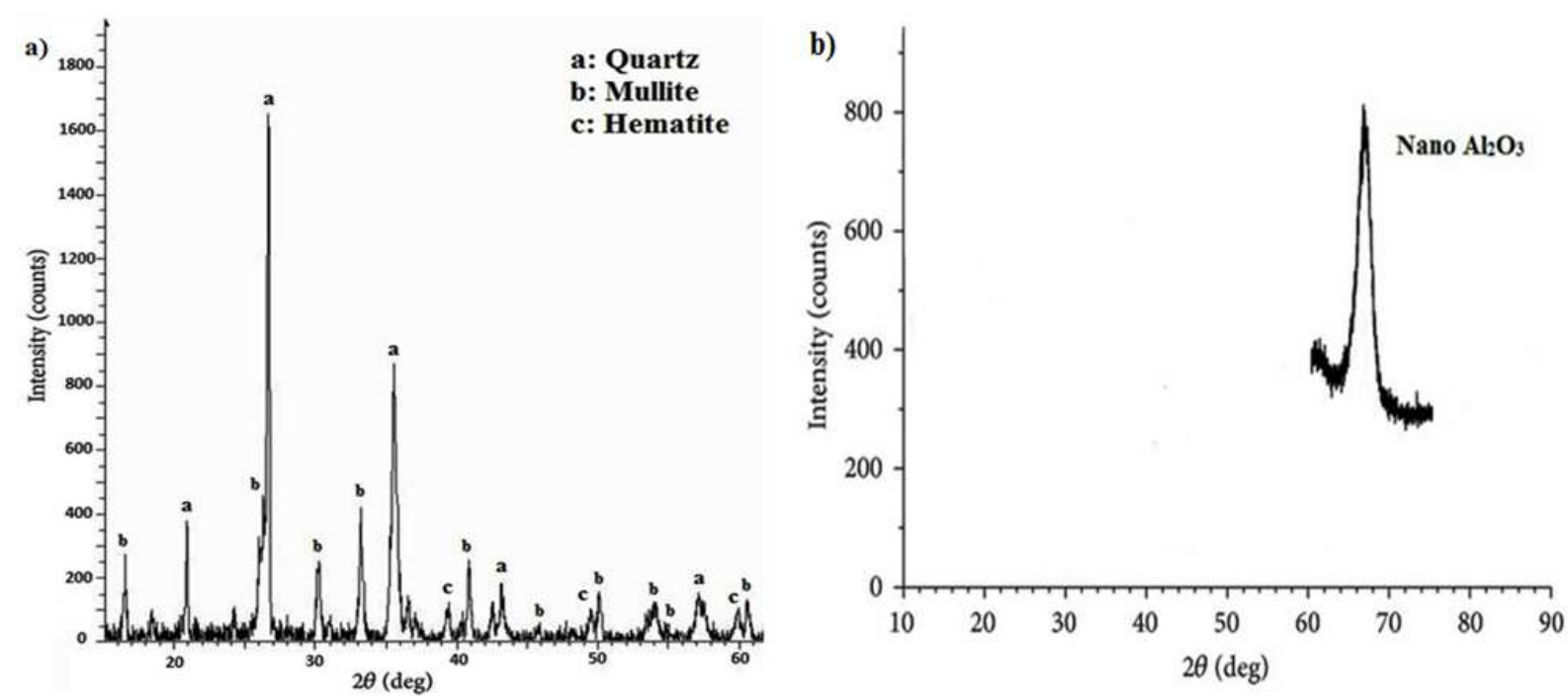

Fig. 1. $\mathrm{XRD}$ analysis of (a) FA and (b) $\mathrm{Al}_{2} \mathrm{O}_{3}$ nanoparticles

Table 1. Chemical composition and physical properties of ordinary Portland cement and fly ash

\begin{tabular}{lcc}
\hline Chemical analysis (\%) & Cement & Fly ash \\
\hline $\mathrm{SiO}_{2}$ & 21.56 & 55.80 \\
$\mathrm{Al}_{2} \mathrm{O}_{3}$ & 6.67 & 20.75 \\
$\mathrm{Fe}_{2} \mathrm{O}_{3}$ & 6.17 & 6.66 \\
$\mathrm{CaO}$ & 49.88 & 4.12 \\
$\mathrm{MgO}$ & 4.51 & 1.90 \\
$\mathrm{SO}_{3}$ & 2.75 & 0.44 \\
$\mathrm{~K}_{2} \mathrm{O}$ & 0.76 & 1.73 \\
$\mathrm{Na}_{2} \mathrm{O}$ & 0.43 & 0.78 \\
$\mathrm{LOI}$ & 2.79 & 1.95 \\
Specific gravity $\left(\mathrm{g} / \mathrm{cm}^{3}\right)$ & 3.15 & 2.20 \\
Specific surface area $\left(\mathrm{cm}^{2} / \mathrm{g}\right)$ & 3250.00 & 5230.00 \\
\hline
\end{tabular}

Table 2. Mixture details of SCMs

\begin{tabular}{lllllll}
\hline $\begin{array}{l}\text { Sample } \\
\text { ID }\end{array}$ & $\begin{array}{l}\mathrm{Cement} \\
\left(\mathrm{kg} / \mathrm{m}^{3}\right)\end{array}$ & $\begin{array}{l}\mathrm{FA} \\
\left(\mathrm{kg} / \mathrm{m}^{3}\right)\end{array}$ & $\begin{array}{l}\mathrm{Al}_{2} \mathrm{O}_{3} \\
\left(\mathrm{~kg} / \mathrm{m}^{3}\right)\end{array}$ & $\begin{array}{l}\text { Water } \\
\left(\mathrm{kg} / \mathrm{m}^{3}\right)\end{array}$ & $\begin{array}{l}\text { Sand } \\
\left(\mathrm{kg} / \mathrm{m}^{3}\right)\end{array}$ & $\begin{array}{l}\mathrm{SP} \\
\left(\mathrm{kg} / \mathrm{m}^{3}\right)\end{array}$ \\
\hline Control & 525 & 175 & 0 & 280 & 1210 & 4.2 \\
1\%NA & 518 & 175 & 7 & 280 & 1198 & 3.8 \\
3\%NA & 504 & 175 & 21 & 280 & 1176 & 3.9 \\
5\%NA & 490 & 175 & 35 & 280 & 1153 & 4.2 \\
\hline
\end{tabular}

Water absorption, electrical resistivity and chloride permeability tests were carried out for determination of durability properties of the mortar mixtures.

The water absorption test was performed conforming to (ASTM, 2013). For every absorption value, the test results were chosen as the average of three test specimens. Specimens were dried after 90 days immersing in the water by being placed in a ventilated oven at a temperature of $105 \pm 5^{\circ} \mathrm{C}$ for $24 \mathrm{~h}$. This procedure was repeated until the difference in mass was less than $5 \%$ of the dried sample. The obtained result is recorded as dried mass $\left(\mathrm{M}_{\mathrm{S}}\right)$. To determine the saturated mass $\left(M_{D}\right)$, specimens were immersed in water for $24 \mathrm{~h}$ and then the weight was measured again. This procedure was also continued until the difference in mass was less than $5 \%$ of the heaviest sample. The water absorption (W) is derived as follows Equation 1:

$W=\left(M_{S}-M_{D}\right) / M_{D}$

The electrical resistivity test makes the evaluation of the probability of reinforcement corrosion possible by assessing the electrical resistance of the concrete as the corrosion of steel in concrete is an electro-chemical process, which provides a current flow causing the metal to dissolve.

For the electrical resistivity test, cubed samples with dimensions of $50 \times 50 \times 50 \mathrm{~mm}$ were prepared and measured at 90 days. The resistivity test contains an electrical resistance measurement device and two electrodes which are attached to both sides of the samples and the resistivity values $\rho$ can be calculated using Equation 2:

$\rho=R A / L$

Where:

$L=$ The length of the measured sample

$R=$ The resistance

$A=$ The cross-sectional area and

Rapid Chloride Permeability Test (RCPT) was performed conforming to the (AASHTO T 277-86, 1990) at the age of 90 days. In the RCPT test the total charge passing through a $50 \mathrm{~mm}$ thick concrete specimen in $6 \mathrm{~h}$ by 60 voltage potential was evaluated. The specimen in the RCPT test cell was in contact with a 0.3 molar solution of $\mathrm{NaOH}$ on one face and with $3 \%$ solution of $\mathrm{NaCl}$ on the other face. It should be mentioned that the achieved results show the strength of specimens against chloride permeability, not the samples permeability. 


\section{Result and Discussion}

\section{Fresh Properties of Self-Compacting Mortar}

Standard slump tests conforming to EFNARC (2005) were performed to determine the workability of the mortars.

The slump flow diameter of the specimens ranges between 24.5 and $25.0 \mathrm{~cm}$ while the $\mathrm{V}$-funnel flow time, $\mathrm{s}$, ranges between 10 and $11 \mathrm{~s}$. As it is shown in Table 3, NA with a ratio of $5 \%$ had the highest slump flow diameter of $25 \mathrm{~cm}$ and the lowest $\mathrm{V}$-funnel flow time of 10 s, respectively. It is observed that the addition of NA slightly increased the flow diameter of the mixtures. The control specimen had a slump flow diameter of $24.5 \mathrm{~cm}$ and the diameter was increased until $25 \mathrm{~cm}$ when $5 \mathrm{wt} \%$ NA was added to the mixture.

Results indicate that the amount of V-funnel flow time slightly reduced with increasing the content of nanoparticles. In fact, the highest V-funnel flow time was observed in the specimens with the lowest percentage of nanoparticle. The same trend was also observed in the flow diameter test; the workability was improved by the addition of nanoparticles.

\section{Compressive Strength}

Table 4 indicates the compressive strength results of mortar mixtures containing $\mathrm{Al}_{2} \mathrm{O}_{3}$. According to the results, the compressive strength of the specimens was decreased by the addition of NA up to $1 \mathrm{wt} \%$. However, the compressive strength of all specimens was higher than that of the control specimen, except for a sample with $5 \mathrm{wt} \% \mathrm{NA}$ at the age of 3 days. This result may occur due to the excessive amount of $\mathrm{Al}_{2} \mathrm{O}_{3}$ nanoparticles. Agarkar and Joshi (2012) also supported this observation; the results revealed that adding up to $1 \% \mathrm{Al}_{2} \mathrm{O}_{3}$ the compressive strength was increased. Beyond $1 \%$, a decrease in compressive strength was observed (Agarkar and Joshi, 2012). Arefi et al. (2011) concluded that the compressive strength of the mixtures decreases after replacing $3 \% \mathrm{wt} \mathrm{Al}_{2} \mathrm{O}_{3}$ nanoparticles with cement. The proper amount of nanoparticles and the distance between them affect the process of crystallization and have capability to control the growth of $\mathrm{Ca}(\mathrm{OH})_{2}$ crystals, thus, these phenomena make the cement matrix homogenous and compact (Nazari and Riahi, 2011d). Furthermore, the strength of the specimens is improved. However, with increasing the ratio of nanoparticles the distance between them is reduced. As a result, the $\mathrm{Ca}(\mathrm{OH})_{2}$ cannot develop satisfactorily. In this case, the ratio of $\mathrm{Ca}(\mathrm{OH})_{2}$ crystals to $\mathrm{C}-\mathrm{S}-\mathrm{H}$ gel is decreased and the weak microstructure of cement matrix results, which leads to a deficiency in the strength (Nazari and Riahi, 2011d). Moreover, the excess NA decreased the water to binder ratio, leading to an inadequate development of hydration.

\begin{tabular}{lll}
\multicolumn{3}{l}{ Table 3. Fresh properties of mortars } \\
\hline & $\begin{array}{l}\text { Slump flow } \\
\text { diameter }(\mathrm{cm})\end{array}$ & $\begin{array}{l}\text { V-funnel } \\
\text { Sample ID }\end{array}$ \\
\hline Control & 24.5 & 11.0 \\
$1 \% \mathrm{NA}$ & 24.8 & 10.6 \\
$3 \% \mathrm{NA}$ & 24.8 & 10.0 \\
$5 \% \mathrm{NA}$ & 25.0 & 10.0 \\
\hline
\end{tabular}

Table 4. Compressive strength of nano- $\mathrm{Al}_{2} \mathrm{O}_{3}$ particle blended mortar specimens

\begin{tabular}{lllll}
\hline & \multicolumn{1}{l}{ Compressive strength in MPa-enhancement (\%) } \\
Sample & - & - & & \\
ID & 3 days & 7 days & 28 days & 90 days \\
\hline Control & $12.13(100)$ & $23.56(100)$ & $37.4(100)$ & $47.43(100)$ \\
$1 \% \mathrm{NA}$ & $13.9(114)$ & $27.9(118)$ & $43.65(116)$ & $54.52(114)$ \\
3\%NA & $13.65(112)$ & $27.22(115)$ & $42.56(113)$ & $53.25(112)$ \\
5\%NA & $12(98)$ & $26.85(113)$ & $41.9(112)$ & $52.54(110)$ \\
\hline
\end{tabular}

Figure $2 \mathrm{a}$ and $2 \mathrm{~b}$ demonstrate the SEM micrograph of SCMs without and with NA, respectively. The micrograph of the mortar with NA revealed a dense, more homogenous and compact formation of NA samples (Fig. 2b). The influential role of NA can stand due to the importance of the nanoparticles into compaction of the mixture microstructure.

\section{Water Absorption}

The water absorption of SCMs incorporating NA at various ratios is depicted in Fig. 3. A similar trend in samples containing different ratios of NA can be seen by increasing the amount of nanoparticles. As it can be observed from the results, the water absorption in the mixtures with NA was increased significantly by replacing the nanoparticles. Oltulu and Sahin (2013) also reported that replacing $\mathrm{Al}_{2} \mathrm{O}_{3}$ nanoparticles, the water absorption of specimens was enhanced (Oltulu and Sahin, 2013). The addition of NA into mixtures at a proportion of $1 \%$, decreased the water absorption by about $4.2 \%$ which was the highest level of decrease compared to the other samples. When increasing more than $1 \%$ NA, the absorption value was increased and reached the highest amount in specimens with 5\% NA. Although this increase was observed, the water absorption is still lower than that of the control sample. As the SEM image shows in Fig. 4, the increased content of nanoparticles weakens the refinement of the pore structure of the mortar. This might happen due space limitations associated with the decrease of the distance between nanoparticles existing in higher concentration, thereby, limiting the formation of $\mathrm{Ca}(\mathrm{OH})_{2}$ crystals. As a result, the ratio of crystals to $\mathrm{C}-\mathrm{S}-\mathrm{H}$ gel is reduced and the water absorption tends to increase. The increase in water absorption in samples with a relatively high content of nanoparticles is also associated with the decreased ratio of the ordinary Portland cement, which reduces the hydration products in specimens. 



Fig. 2. SEM micrograph of $\mathrm{SCM}$ (a) without $\mathrm{Al}_{2} \mathrm{O}_{3}$ nanoparticles and (b) with $1 \% \mathrm{Al}_{2} \mathrm{O}_{3}$ nanoparticles at 28 days

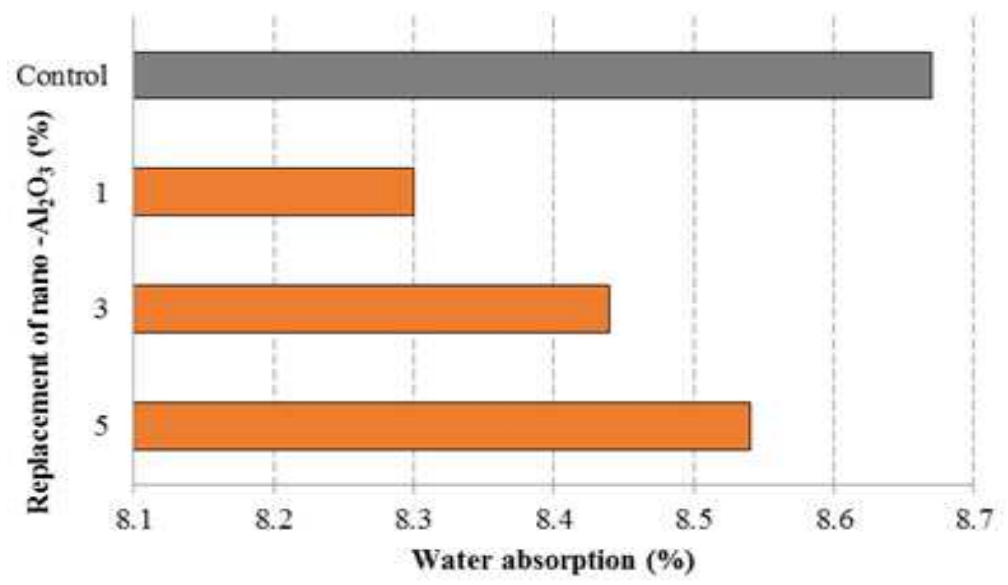

Fig. 3. Percentage of water absorption of nano- $\mathrm{Al}_{2} \mathrm{O}_{3}$ particle blended mortar specimens



Fig. 4. SEM micrograph of $\mathrm{SCM}$ with $5 \% \mathrm{Al}_{2} \mathrm{O}_{3}$ nanoparticles at 28 days 




Fig. 5. Electrical resistivity values for specimens containing $\mathrm{Al}_{2} \mathrm{O}_{3}$ nanoparticles as Per ACI Committee 222

Table 5. MIP and BET results of specimens

\begin{tabular}{|c|c|c|c|c|c|c|c|c|c|c|c|}
\hline \multirow{3}{*}{$\begin{array}{l}\text { Sample } \\
\text { ID }\end{array}$} & \multicolumn{7}{|l|}{ MIP analysis } & \multicolumn{4}{|c|}{ BET Analysis } \\
\hline & \multirow{2}{*}{$\begin{array}{l}\text { Volume of } \\
\text { cumulative mercury } \\
\text { intruded }\left(\mathrm{cm}^{3} / \mathrm{g}\right)\end{array}$} & \multicolumn{6}{|c|}{ Pore proportions (\%) classified by diameter (nm) } & \multirow{2}{*}{$\begin{array}{l}\text { Specific } \\
\text { surface } \\
\text { area }\left(\mathrm{m}^{2} / \mathrm{g}\right)\end{array}$} & \multicolumn{3}{|c|}{$\begin{array}{l}\text { Pore proportions }(\%) \\
\text { classified by diameter }(\mathrm{nm})\end{array}$} \\
\hline & & $4-10$ & $10-50$ & $50-100$ & $100-500$ & $500-1000$ & $>1000$ & & $<2.5$ & $2.5-10$ & $>10$ \\
\hline Control & 0.0412 & 48 & 39 & 6 & 2 & & 5 & 4.9 & 1 & 47 & 52 \\
\hline $1 \% \mathrm{NA}$ & 0.0168 & 44 & & & 36 & 12 & 8 & 7.3 & 14 & 46 & 40 \\
\hline $3 \% \mathrm{NA}$ & 0.0254 & 54 & 32 & & 4 & 6 & 4 & 6.1 & 10 & 49 & 41 \\
\hline $5 \% \mathrm{NA}$ & 0.0359 & 56 & 25 & 14 & & 3 & 2 & 5.6 & 6 & 48 & 46 \\
\hline
\end{tabular}

According to the MIP and BET analyses, the porosity of mixtures increases when a replacement ratio for NA of more than $1.0 \%$ was used in mixtures (Table 5).

By using nanoparticles the water absorption was generally decreased compared to the control mixture. It could be due to the fact that nanoparticles fill the voids in specimens, consequently the water absorption attenuated. As the water absorption test illustrates the volume of the voids in cement-based materials, it can be reported that NA particles can reduce the volume of pores in the mixtures and therefore the water absorption level decreases compared to the control sample.

\section{Electrical Resistivity}

The electrical resistivity results which indicate the corrosion probability level are compared with the limits suggested by (ACI Committee 222, 2001) and are drawn in Fig. 5. It was observed that the electrical resistivity decreased in samples containing NA nanoparticles when replacement rate of admixtures was increased. Particularly, in the $5 \%$ NA sample, the electrical resistivity reduced by about $22 \%$ compared with the mortars containing $1 \% \mathrm{NA}$, but it is still much higher than that of the control specimen. The influential role of nanoparticles leads to increasing the electrical resistivity which is because of the importance of nanoparticles into compacting of the microstructure of mixtures. In fact, the better the compaction, the higher the electrical resistivity is. Moreover, it might be deducted that the increase in electrical resistivity is due to an increase in paste volume by replacing nanoparticles, resulting in the augmentation of resistance. In other words, the nanoparticles act as good inhibitors against the electricity flow. Thus, specimens incorporating NA rarely experience high corrosion rates. Resulting from the current test, 1\% NA is considered as the ideal proportion of nano- $\mathrm{Al}_{2} \mathrm{O}_{3}$.

According to ACI 222R-01 (ACI Committee 222, 2001 ), specimens containing $10-20 \mathrm{k} \Omega . \mathrm{cm}$ of electrical sensitivity (which is similar to our case study with different percentages of $\mathrm{Al}_{2} \mathrm{O}_{3}$ ) fall within low-tomoderate corrosion rate category. In the current study, the electrical resistivity of the control sample is between $5-10 \mathrm{k} \Omega . \mathrm{cm}$, which falls within the high corrosion rate category, as it is shown in Fig. 5. 


\section{Rapid Chloride Permeability Test (RCPT)}

The total charges passed indicate the level of chloride ion penetration through the mortars and were compared with the limits suggested in (AASHTO), as shown in Fig. 6. The results demonstrate that using nano-particles influenced positively the chloride permeability of the mixtures. Mixtures with 3\% NA experienced the lowest charge passed compared to other combinations and they can be categorized as low chloride permeability (Fig. 6). Although mixtures incorporating 5\% NA resulted the highest level of charge passed and had more resistance to chloride permeability compared to the control one (Fig. 6), they categorized as moderate chloride permeability. In general, the chloride permeability of the specimens was decreased by using nanoparticles. In other words, the resistance to chloride penetration of concrete may attribute to the pore structures refinement. The lower the percentage of the chloride content is achieved, the better the durability of the sample is.

It was concluded from the results that nanoparticles fulfill a momentous function in reducing the amount of chloride permeability with disparate ratios. The rate of chloride penetration into mortar is dependent on the interconnectivity of the pore network and chloride binding capacity of the mixture, which developed by the addition of NA particles.

The chloride binding ability of the hydrated phases is typically considered as the relationship between bound chlorides in hydrated phases and free $\mathrm{Cl}^{-}$ions in the pore solution. In cement-based materials, $\mathrm{Cl}^{-}$ions are bound by the $\mathrm{C}-\mathrm{S}-\mathrm{H}$ phase due to its high specific surface (Ioannou et al., 2015). As a result, the presence of NA and FA accelerate the $\mathrm{C}-\mathrm{S}-\mathrm{H}$ formation phase, which directs in higher bound $\mathrm{Cl}^{-}$in mixtures. This phenomenon leads to a decrease in the chloride permeability of mortars.

The chloride binding capacity is monitored by the cementitious materials used in the mortar. The inclusion of supplementary cementitious materials, such as fly ash, affects binding, though the exact influence is unclear (Byfors, 1986; Sandberg and Larsson, 1993; Thomas et al., 1995; Holden et al., 1996). Furthermore, the binding capacity of the cement is influenced by its $\mathrm{C}_{3}$ A content, thereby, the increased $\mathrm{C}_{3} \mathrm{~A}$ content leads to an increase in binding (Holden et al., 1996; Midgley and Illston, 1984; Hansson and Sorenson, 1990).

\section{MIP and BET Analyses Results}

The total volume of mercury intruded, porosity and the specific surface area obtained from the MIP and BET analyses are given in Table 5. The pore proportions listed by diameter and were determined from the volume of cumulative mercury intruded in the pore size interval to the total mercury volume within the specimen. As an example, for the control specimen, the pore proportion between 4 and $10 \mathrm{~nm}$ is $48 \%$ of the whole pore volume (Fig. 7). The total volume of mercury intruded decreases with NA particles replacement up to $1.0 \%$ and then it increases, although the mercury volume of $5.0 \%$ replacement is still lower than this of the plain cement mortar. In fact, the pore volume of the specimens is generally reduced by the addition of NA particles compared to the control sample. The addition of NA into the specimens in proportions of 1, 3 and 5\% decreased the total pore volume by 59,38 and $12 \%$, respectively, compared to the control specimen.

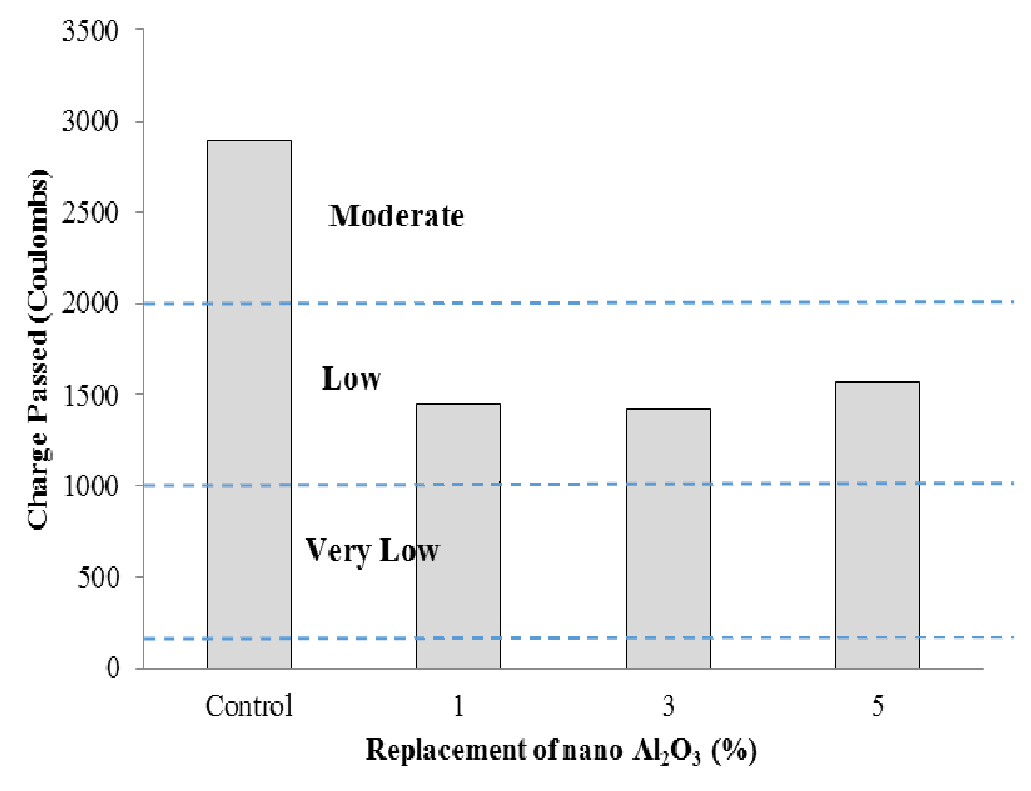

Fig. 6. Rapid Chloride Penetration Test (RCPT) results as Per ASTM C1202-07 


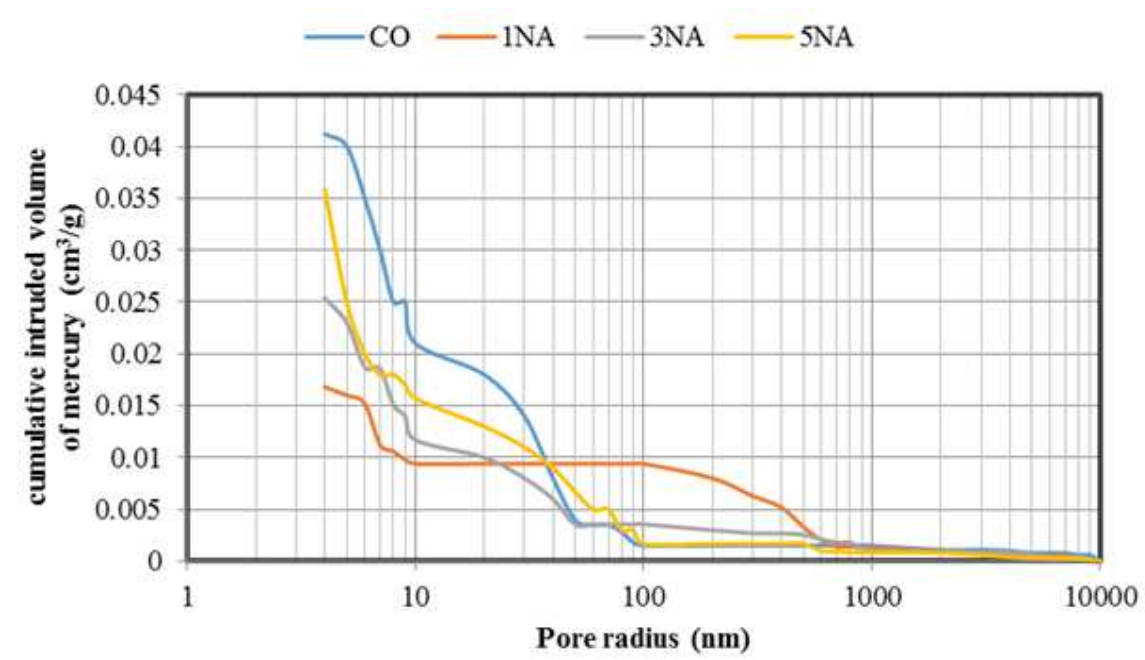

Fig. 7. Pore size distribution curve for the samples containing nano- $\mathrm{Al}_{2} \mathrm{O}_{3}$

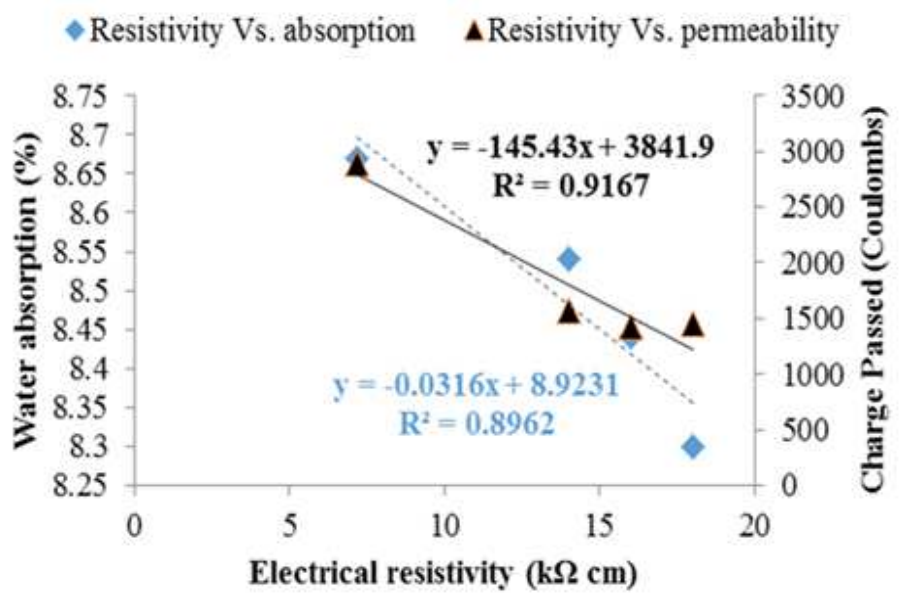

Fig. 8. Correlation between water absorption, electrical resistivity and RCPT

The overall reduced porosity obtained by NA is due to the pore refinement of the nanoparticles. Moreover, NA particles improve the density and homogeneity of the cement matrix by providing a better distribution of $\mathrm{C}-\mathrm{S}-\mathrm{H}$ and by restricting $\mathrm{C}-\mathrm{H}$ crystal growth, which may lead to the blockage of existing pores and hence the change the pore structure (Khotbehsara et al., 2015). Furthermore, it can be concluded that the increasing pore volume of mortars after the addition of $5 \% \mathrm{NA}$ is caused by the nonuniform distribution of nanoparticles in the mortar matrix, resulting in agglomeration and production of more internal pores (Mohseni et al., 2015c).

BET analysis also reveals the distribution of pores in terms of diameter. In BET analysis, the higher specific surface area indicates the smaller pore size. In general, the addition of NA nanoparticles into the mixtures increases the specific surface area. However, the surface area tended to decrease when a replacement ratio for NA of more than $1 \%$ was used in mortars.

The addition of $1 \%$ NA into the mortars increased the specific surface area by $49 \%$ compared to the control specimen. The replacement of nano-particles changed the pore size distributions of the mixtures. As it can be observed from Table 5, the presence of smaller pores $(<2.5)$ was more prevalent when the proportions of NA powder at 1 and $3 \%$ were used in mortars. However, a powder content level of $5 \%$ increased the number of pores larger than $10 \mathrm{~nm}$. In parallel to the MIP results, as NA powder content produced a finer pore structure, also displayed its effect on the other properties of the mortars, such as the compressive strength, the electrical resistivity and the water absorption. For instance, according to the above obtained results, $1 \%$ NA resulted in the highest compressive strength and electrical resistivity and the 
lowest water absorption coefficient. This result is different for 5\% NA specimens.

\section{Correlation between Water Absorption, Electrical Resistivity and RCPT}

Figure 8 shows a standard correlation between the pore structure and the durability properties of FAcontaining SCMs after the NA replacement. As the dosage of NA was increased from 1 to $5 \%$, the enhancement of the pore volume of specimens was observed and its effect on the water absorption, electrical resistivity and RCPT results was displayed. In other words, $5 \%$ NS increased the amount of porosity as well as showed an inefficient effect on the durability of the specimens. This phenomenon demonstrates the effective role of the pore structures on the durability of mortar specimens.

\section{Concluding Remarks}

The results reveal that the mixtures containing NA particles have significantly higher compressive strength in contrast with the control specimen at every age of curing. The optimum level of admixture which could be advantageously replaced by the mixtures was achieved at $1.0 \%$ NA for the compressive test.

Although partial replacement of cement by NA particles reduced the percentage of water absorption of the specimens, the same ratio was increased with the addition of more than $1 \%$ NA. However, the electrical resistivity of the specimens decreased through enhancing the content of nano-particles and reached a minimum in mixtures containing 5\% NA.

In terms of Rapid Chloride Permeability Test (RCPT), the resistance of specimens to chloride permeability was improved using NA, however, when a different amount of NA (1 to 5\%) a relatively similar effect on the $\mathrm{Cl}$ permeability of samples was exhibited and that suggests a research area for future investigation.

A strong relationship was observed between the pore structure and the mechanical and durability properties of SCMs by the addition of the NA. As the dosage of NA increased from 1 to $5 \%$, the enhancement of pore volume of specimens observed, which indicates the inefficient effect of high NA contents on the porosity of mixtures. This trend of effect can be also seen in durability and mechanical properties of mortars.

\section{Acknowledgment}

The first author would like to thank Dr. Malek Mohammad Ranjbar for his help with materials science.

\section{Author's Contributions} work.

\section{Ethics}

There are no ethical issues known to authors that may arise after the publication of this manuscript.

\section{References}

AASHTO T 277-86, 1990. Rapid determination of the chloride permeability of concrete. American Association of States Highway and Transportation Officials, Standard Specifications -Part II Tests, Washington, DC.

ACI Committee 222, 2001. ACI 222R-01: Protection of metals in concrete against corrosion.

Agarkar, S.V. and M.M. Joshi, 2012. Study of effect of $\mathrm{Al}_{2} \mathrm{O}_{3}$ nanoparticles on the compressive strength and workability of blended concrete. Int. J. Curr. Res., 4: 382-384.

Arefi, M.R., M.R. Javeri and E. Mollaahmadi, 2011. To study the effect of adding $\mathrm{Al}_{2} \mathrm{O}_{3}$ nanoparticles on the mechanical properties and microstructure of cement mortar. Life Sci. J., 8: 613-617.

ASTM, 2007a. ASTM C109-93: Standard specification for compressive strength of mortars. American Society for Testing and Materials.

ASTM, 2007b. ASTM C293/C293M-10: Standard test method for flexural strength of concrete. American Society for Testing and Materials.

ASTM, 2013. ASTM C642: Standard test method for density, absorption and voids in hardened concrete. American Society for Testing and Materials.

ASTM, 2001a. ASTM C150: Standard Specification for Portland Cement. In: Annual Book of ASTM standards, American Society for Testing and Materials, Philadelphia, PA.

ASTM, 2001b. ASTM C494 TYPE F: Standard specification for chemical admixtures for concrete. American Society for Testing and Materials.

Barbhuiya, S., S. Mukherjee and H. Nikraz, 2014. Effects of nano- $\mathrm{Al}_{2} \mathrm{O}_{3}$ on early-age microstructural properties of cement paste. Construct. Build. Mater., 52: 189-193.

DOI: $10.1016 /$ j.conbuildmat.2013.11.010

Barbhuiya, S., 2011. Effects of fly ash and dolomite powder on the properties of self-compacting concrete. Construct. Build. Mater., 25: 3301-3305. DOI: 10.1016/j.conbuildmat.2011.03.018

Byfors, K., 1986. Chloride binding in cement paste. Nordic Concrete Res., 5: 27-38.

Chang, T.P., 2007. Material properties of Portland cement paste with nano-montmorillonite. Mater. Sci., 42: 7478-7487. DOI: 10.1007/s10853-006-1462-0

EFNARC, 2005. The European guidelines for selfcompacting concrete specification, production and use. EFNARC. 
Hansson, C.M. and B. Sorenson, 1990. The threshold concentration of chloride in concrete for the initiation of reinforcement corrosion. ASTM, 99: 3-16. DOI: 10.1520/STP25011S

He, X. and X. Shi, 2008. Chloride permeability and microstructure of Portland cement mortars incorporating nanomaterials. J. Trans. Res. Board. DOI: $10.3141 / 2070-03$

Holden, W.R., C.L. Page and N.R. Short, 1996. The Influence of Chlorides and Sulphates on Durability. In: Corrosion of Reinforcement in Concrete Construction, Page, C.L., P.B. Bamforth and J.W. Figg (Eds.), Royal Society of Chemistry, Information Services, Cambridge, pp: 143-150.

Hou, P., K. Wang, J. Qian, S. Kawashima and D. Kong et al., 2012. Effects of colloidal nanoSiO ${ }_{2}$ on fly ash hydration. Cement Concrete Composi., 34: 1095-1103. DOI: 10.1016/j.cemconcomp.2012.06.013

Ioannou, S., K. Paine, L. Reig and K. Quillin, 2015. Performance characteristics of concrete based on a ternary calcium sulfoaluminate-anhydrite-fly ash cement. Cement Concrete Composi., 55: 196-204. DOI: 10.1016/j.cemconcomp.2014.08.009

Jalal, M., E. Mansouri, M. Sharifipour and A.R. Pouladkhan, 2012. Mechanical, rheological, durability and microstructural properties of high performance self-compacting concrete containing $\mathrm{SiO}_{2}$ micro and nanoparticles. Mater. Design, 34: 389-400. DOI: 10.1016/j.matdes.2011.08.037

Kawashima, S., P. Hou, D.J. Corr and S.P. Shah, 2013. Modification of cement-based materials with nanoparticles. Cement Concrete Compos., 36: 8-15. DOI: 10.1016/j.cemconcomp.2012.06.012

Khotbehsara, M.M., M. Mohseni, M.A. Yazdi, P. Sarker and M.M. Ranjbar, 2015. Effect of nano-CuO and fly ash on the properties of self-compacting mortar. Construct. Build. Mater., 94: 758-766.

DOI: 10.1016/j.conbuildmat.2015.07.063

Li, Z., H. Wang, S. He, Y. Lu and M. Wang, 2006. Investigations on the preparation and mechanical properties of the nano-alumina reinforced cement composite. Mater. Lett., 60: 356-359.

DOI: 10.1016/j.matlet.2005.08.061

Madandoust, R., M.M. Ranjbar and S.Y. Mousavi, 2011. An investigation on the fresh properties of selfcompacted lightweight concrete containing expanded polystyrene. Construct. Build. Mater., 25: 3721-3731.

DOI: 10.1016/j.conbuildmat.2011.04.018

Madandoust, R., E. Mohseni, S.Y. Mousavi and M. Namnevis, 2015. An experimental investigation on the durability of self-compacting mortar containing nano-SiO 2 , nano- $\mathrm{Fe}_{2} \mathrm{O}_{3}$ and nano- $\mathrm{CuO}$. Construct. Build. Mater., 86: 44-50.

DOI: 10.1016/j.conbuildmat.2015.03.100
Midgley, H.G. and J.M. Illston, 1984. The penetration of chlorides into hardened cement pastes. Cement Concrete Res., 14: 546-558.

DOI: 10.1016/0008-8846(84)90132-7

Mohseni, E., M.M. Ranjbar, M.A. Yazdi, S.S. Hosseiny and E. Roshandel, 2015a. The effects of silicon dioxide, iron(III) oxide and copper oxide nanomaterials on the properties of self-compacting mortar containing fly ash. Magaz. Concrete Res., 67: 1112-1124. DOI: 10.1680/macr.15.00051

Mohseni, E., M.M. Ranjbar and K.D. Tsavdaridis, 2015b. Durability properties of high-performance concrete incorporating Nano- $\mathrm{TiO}_{2}$ and fly ash. Am. J. Eng. Applied Sci., 8: 519-526.

DOI: 10.3844/ajeassp.2015.519.526

Mohseni, E., B.M. Miyandehi, J. Yang and M.A. Yazdi, 2015c. Single and combined effects of nano- $\mathrm{SiO}_{2}$, nano- $\mathrm{Al}_{2} \mathrm{O}_{3}$ and nano- $\mathrm{TiO}_{2}$ on the mechanical, rheological and durability properties of selfcompacting mortar containing fly ash. Construct. Build. Mater., 84: 331-340.

DOI: 10.1016/j.conbuildmat.2015.03.006

Morsy, M.S., S.H. Alsayed and M. Aqel, 2010. Effect of nano-clay on mechanical properties and microstructure of ordinary Portland cement mortar. Int. J. Civil Environ. Eng., 10: 23-17.

Nazari, A. and S. Riahi, 2011a. Effects of $\mathrm{Al}_{2} \mathrm{O}_{3}$ nanoparticles on properties of self compacting concrete with Ground Granulated Blast Furnace Slag (GGBFS) as binder. Sci. China Technol. Sci., 54: 2327-2338. DOI: 10.1007/s11431-011-4440-y

Nazari, A. and S. Riahi, 2011b. $\mathrm{Al}_{2} \mathrm{O}_{3}$ nanoparticles in concrete and different curing media. Energy Build., 43: 1480-1488. DOI: 10.1016/j.enbuild.2011.02.018

Nazari, A. and S. Riahi, 2011c. The effects of curing medium on flexural strength and water permeability of concrete incorporating $\mathrm{TiO}_{2}$ nanoparticles. Mater. Structures, 44: 773-786. DOI: $10.1617 / \mathrm{s} 11527-010-9664-\mathrm{y}$

Nazari, A. and S. Riahi, 2011d. Abrasion resistance of concrete containing $\mathrm{SiO}_{2}$ and $\mathrm{Al}_{2} \mathrm{O}_{3}$ nanoparticles in different curing media. Energy Build., 43: 2939-2946. DOI: 10.1016/j.enbuild.2011.07.022

Oltulu, M. and R. Sahin, 2013. Effect of nano- $\mathrm{SiO}_{2}$, nano- $\mathrm{Al}_{2} \mathrm{O}_{3}$ and nano- $\mathrm{Fe}_{2} \mathrm{O}_{3}$ powders on compressive strengths and capillary water absorption of cement mortar containing fly ash: A comparative study. Energy Build., 58: 292-301. DOI: 10.1016/j.enbuild.2012.12.014

Qian, K., M. Tao, Q. Xiao-Qian and Z. Shu-Lin, 2009. Research on some properties of fly ash concrete with nano- $\mathrm{CaCO}_{3}$ middle slurry. Key Eng. Mater., 405-406: 186-190.

DOI:

10.4028/www.scientific.net/KEM.405-406.186 
Rashad, M.A., 2013. A synopsis about the effect of nano- $\mathrm{Al}_{2} \mathrm{O}_{3}$, nano- $\mathrm{Fe}_{2} \mathrm{O}_{3}$, nano- $-\mathrm{Fe}_{3} \mathrm{O}_{4}$ and nano-clay on some properties of cementitious materials-a short guide for civil engineer. Mater. Des., 52: 143-157. DOI: $10.1016 /$ j.matdes.2013.05.035

Safiuddin, M.D., J.S. West and K.A. Soudki, 2010. Flowing ability of the mortars formulated from selfcompacting concretes incorporating rice husk ash. Construct. Build. Mater., 25: 973-978.

DOI: 10.1016/j.conbuildmat.2010.06.084

Sandberg, P. and J. Larsson, 1993. Chloride Binding in Cement Pastes in Equilibrium with Synthetic Pore Solutions. In: Chloride Penetration into Concrete Structures, Nordic Miniseminar, Nilsson, L.O. (Ed.), CUT, pp: 98-107.
Thomas, M.D.A., S.J. Pantazopoulou and B. Martin-Perez, 1995. Service life modelling of reinforced concrete structures exposed to chlorides-A literature review. University of Toronto.

Yang, J., E. Mohseni, B. Behforouz and M.M. Khotbehsara, 2015. An experimental investigation into the effects of $\mathrm{Cr}_{2} \mathrm{O}_{3}$ and $\mathrm{ZnO}_{2}$ nanoparticles on the mechanical properties and durability of selfcompacting mortar. Int. J. Mater. Res., 106: 886-892. DOI: $10.3139 / 146.111245$ 